MOLECULAR BIOLOGY

\title{
Stem-cell progress
}

\section{Replacing genes with drugs could allow safe reprogramming.}

\section{BY EWEN CALLAWAY}

$\mathrm{E}$ ver since scientists first switched adult human cells into an embryonic-like state from which they can develop into any tissue type, recipes for making these induced pluripotent stem (iPS) cells have multiplied.

However, many rely on the introduction of foreign genes by viruses, which makes the altered cells unsuitable for use in patients. Now researchers have replaced all but one of the genes with a cocktail of chemicals, taking scientists a step closer to creating patient-specific iPS cells that could be used in the clinic.

The advance, by chemist Sheng Ding at the Scripps Research Institute in San Diego, California, and his colleagues (Zhu, S. et al. Cell Stem Cell 7, 651-655; 2010) is an adaptation of an approach developed by Shinya Yamanaka's lab at Kyoto University in Japan. Yamanaka's group - one of two to first create iPS cells infected adult cells with viruses carrying the genes OCT3/4, SOX2, KLF4 and c-MYC.
However, these iPS cells have foreign DNA peppered throughout their genomes, where it might interrupt genes that protect against tumours. Over the past few years, scientists such as Ding have developed safer ways to make pluripotent cells, by delivering reprogramming factors in other ways (see 'Virusfree iPS cells').

In 2008, Ding's team showed that a mixture of chemicals and two genes could reprogram

\section{VIRUS-FREE IPS CELLS}

\begin{tabular}{l|l}
$\begin{array}{l}\text { Reprogramming-factor } \\
\text { delivery method }\end{array}$ & Pros \\
\hline Proteins & No foreign genes involved \\
\hline Transposons & $\begin{array}{l}\text { Just one piece of DNA is } \\
\text { inserted into the genome } \\
\text { Quicker and more efficient } \\
\text { than other methods } \\
\text { Ro foreign genes, } \\
\text { RNA }\end{array}$ \\
\hline Small moleculially cheap to make
\end{tabular}

neural progenitor cells, which already express other genes needed to make iPS cells (Shi, Y. et al. Cell Stem Cell 2, 525-528; 2008). Now his group has made human iPS cells from skin cells by treating them with drugs and just one virus-delivered gene, OCT4. The resulting cells express the same genes as embryonic stem cells and can transform into different types of cell.

OCT4 can be replaced as well, so an iPS protocol entirely free of foreign genes shouldn't be far off. Ding says that his team has already created mouse iPS cells using only drugs, and is making progress with human cells.

Robert Lanza, chief scientific officer of Advanced Cell Technology in Marlborough, Massachusetts, says that iPS cells should soon be safe enough to test in humans. "I think we now have the tools to contemplate clinical trials."

\section{Cons}

Protein modifications could influence reprogramming, expensive to manufacture

The transposon must be removed using a specialized enzyme

Potential for immune response, expensive to manufacture

Drugs can affect unintended protein targets 